\title{
Homogenized Porcine Extracellular Matrix Derived Injectable Tissue Construct with Gold Nanoparticles for Musculoskeletal Tissue Engineering Applications
}

\author{
Sarah E. Smith ${ }^{1}$, Colten L. Snider ${ }^{1}$, David R. Gilley ${ }^{2}$, Daniel N. Grant ${ }^{3}$, Seth L. Sherman", \\ Bret D. Ulery ${ }^{5}$, David A. Grant ${ }^{1}$, Sheila A. Grant ${ }^{1 *}$ \\ ${ }^{1}$ Department of Bioengineering, University of Missouri, Columbia, Missouri, USA \\ ${ }^{2}$ School of Medicine, University of Missouri, Columbia, Missouri, USA \\ ${ }^{3}$ University of Missouri, Columbia, Missouri, USA \\ ${ }^{4}$ Department of Orthopaedic Surgery, University of Missouri, Columbia, Missouri, USA \\ ${ }^{5}$ Department of Chemical Engineering, University of Missouri, Columbia, Missouri, USA \\ Email: sesmith@mail.missouri.edu, clsytc@mail.missouri.edu, Drgn74@health.missouri.edu, grantdan@health.missouri.edu, \\ shermanse@health.missouri.edu, uleryb@missouri.edu, grantdav@missouri.edu, ’grantsa@missouri.edu
}

How to cite this paper: Smith, S.E., Snider, C.L., Gilley, D.R., Grant, D.N., Sherman, S.L., Ulery, B.D., Grant, D.A. and Grant, S.A. (2017) Homogenized Porcine Extracellular Matrix Derived Injectable Tissue Construct with Gold Nanoparticles for Musculoskeletal Tissue Engineering Applications. Journal of Biomaterials and Nanobiotechnology, 8, 125-143.

https://doi.org/10.4236/jbnb.2017.82009

Received: December 28, 2016

Accepted: April 23, 2017

Published: April 26, 2017

Copyright $\odot 2017$ by authors and Scientific Research Publishing Inc. This work is licensed under the Creative Commons Attribution International License (CC BY 4.0).

http://creativecommons.org/licenses/by/4.0/ (c) (i) Open Access

\begin{abstract}
A unique porcine extracellular matrix (ECM) derived injectable tissue construct with $100 \mathrm{~nm}$ or $20 \mathrm{~nm}$ gold nanoparticles (AuNP) was developed for musculoskeletal tissue engineering applications. ECM has been shown to encourage cellularity and tissue remodeling due to its release of growth factors while AuNP have been shown to reduce reactive oxygen species (ROS) levels. Injectable tissue constructs were created by homogenizing decellularized porcine diaphragm tendon conjugated with $100 \mathrm{~nm}$ or $20 \mathrm{~nm}$ AuNP at $1 \mathrm{x}, 4 \mathrm{x}$, and $8 \mathrm{x}$ concentrations. Extrusion force testing demonstrated that homogenized tissue constructs were injectable at an appropriate cannula size and force. L-929 murine fibroblasts were used to measure cell viability, cell proliferation, intracellular ROS levels, and cell migration in response to constructs. Enhanced cell viability and proliferation are observed on $1 \times 20 \mathrm{~nm}$ AuNP constructs. ROS assays demonstrate reduced cellular ROS concentrations from all $20 \mathrm{~nm}$ AuNP constructs and from $8 \times 100 \mathrm{~nm}$ AuNP constructs compared with constructs without nanoparticles. Cellular migration is higher towards $4 \times 20 \mathrm{~nm}$ AuNP constructs compared with constructs without nanoparticles. Results support the potential use of a porcine ECM derived injectable tissue construct with AuNP as an injectable tissue construct to reduce inflammation and to promote tissue remodeling in musculoskeletal tissue engineering applications.
\end{abstract}




\section{Keywords}

Extracellular Matrix, Gold Nanoparticles, Homogenization, Cell Viability, Cell Migration

\section{Introduction}

ECM based scaffolds are becoming increasingly popular in musculoskeletal tissue engineering [1]. These decellularized scaffolds have a lower inflammatory response and improved cellular integration compared with synthetic materials [2]. In addition, the ECM contains cytokines and growth factors such as transforming growth factor beta, keratinocyte growth factor, and platelet derived growth factor that promote constructive tissue remodeling as the ECM naturally degrades [1]. Degraded ECM products have also been shown to have chemotactic properties for fibroblasts and for some macrophages which may enhance ECM production [3] [4] [5]. ECM contains points of cellular attachment providing an ideal environment for proliferation [1].

While there are many benefits of using ECM based graft materials, their application can be limited due to their form as a graft material. Creating an ECM based material that can be delivered by injection expands the benefits of ECM to a wider variety of applications including myocardial infarction [6], reconstruction of skeletal muscle [7], and musculoskeletal applications [8], urinary incontinence [9], adipose tissue engineering [10], and orthopaedic applications such as meniscus repair [11]. Here we developed an injectable ECM-based tissue construct for musculoskeletal tissue engineering applications such as post-traumatic osteoarthritis (PTOA), rheumatoid arthritis, and osteoporosis. In these diseases, there is wear in the cartilage of the joint that causes painful bone on bone wear. Therapies to address short-term symptoms include intra-articular injections of pain killers, anti-inflammatory agents, corticosteroid, or hyaluronic acid. Unfortunately, these therapies only offer temporary pain relief. There is little midterm or long-term benefit due to the rapid breakdown of the therapeutic agents and the failure to alleviate the cause of symptoms. None of these treatments provide effective long-term relief while maintaining natural joint functionality. The use of an injectable ECM scaffold may be used to fill cartilage defects, mitigate cartilage degradation and promote remodeling.

An ideal tissue construct for musculoskeletal applications should provide an environment that reduces inflammation and promotes tissue remodeling in order to repair tissue defects. Inflammation can cause damage to tissue in the form of reactive oxygen species (ROS). Reducing ROS levels may mitigate the damaging effects to the tissue and prevent the quick break down of remodeled tissue. Tissue remodeling requires cell migration, attachment, and proliferation to remodel tissue. An ideal construct would provide an environment that stimulates cellularity in order to repair tissue defects.

AuNP have been increasingly used in tissue engineering due to myriad bene- 
fits including biocompatibility, promotion of remodeling, and ability to reduce inflammation [12] [13] [14]. It has also been shown that the conjugation of AuNP to ECM tissue scaffolds enhances remodeling in vivo [15]. This remodeling influence can be attributed to an increase in cellularity and GAG production in the presence of AuNP [16]. AuNP can increase migration and adhesion of cells to tissue scaffolds due to AuNP' increased surface energy or due the creation of a topography favoring cell attachment [16]. In addition, it is suggested that AuNP may block binding sites for collagenase, slowing in vivo degradation [16]. Gold and specifically AuNP have been used as an anti-inflammatory agent for many years [17] [18] [19]. AuNP are zerovalent, have high surface reactivity, and are resistant to oxidation. Studies have demonstrated gold's usefulness as a therapeutic treatment for diseases such as chronic inflammation and rheumatoid arthritis [20]. This reduction in inflammation may be attributed to anti-oxidative effects of AuNP. Several studies have shown the effectiveness of using AuNP as a free radical scavenger [21] [22]. It was determined that AuNP act as antioxidative agents by inhibiting the formation of ROS and scavenging free radicals, which lowered oxidative stress levels in mice [22]. The mechanism by which AuNP inhibit oxidative stress has not been completely determined. One theory suggests that AuNP inhibit lipids from peroxidation [23] [24]; other theories state that AuNP can restore metabolic enzymes damaged by hyperglycemia [22], normalize bile action [25], and interact with thioredoxin, a conserved thiol reductase that participates in the regulation of cellular redox balance [26].

Here we developed an ECM-AuNP based tissue construct for musculoskeletal tissue engineering applications with the hypothesis that the presence of AuNP will promote cellularity while mitigating inflammation. AuNP were aminefunctionalized and conjugated to decellularized porcine diaphragm tendon. The tissue was then homogenized into an injectable form to be delivered to the defect. In addition to the benefits of ECM and AuNP as previously discussed, there are several benefits to using a combined ECM/AuNP construct. By conjugating the AuNP to the ECM, the native microstructure of the ECM is maintained while enhancing stability and allowing cellular integration. The crosslinking treatment used in the conjugation of AuNP slows tissue degradation which allows additional time for neo-cartilage formation and longer lasting anti-inflammatory effects. AuNP are conjugated to tissue to prevent "wash-out" and to maintain effectiveness for longer periods of time compared to attachment by nanoparticle adsorption to the tissue. By homogenizing the tissue, the benefits of ECM and AuNP can be delivered to the defect site in an injectable form.

\section{Methods}

\subsection{Preparation of Constructs}

\subsubsection{Tissue Harvest and Decellularization}

Porcine tissue (diaphragm) was harvested immediately after euthanization at the University of Missouri, School of Medicine (Columbia, MO). The central diaph- 
ragm tendon was dissected from surrounding tissue and stored in Tris Buffer solution consisting of $5 \mathrm{mM}$ ethylenediaminetetraacedic acid (EDTA), $0.4 \mathrm{mM}$ phenylmethylsulfonyl (PMSF), and $0.2 \%(\mathrm{w} / \mathrm{v})$ sodium azide $(\mathrm{pH}=8.0)$ at $4^{\circ} \mathrm{C}$. Tissue was decellularized in a $1 \%(\mathrm{v} / \mathrm{v}) \operatorname{tri}(n$-butyl) phosphate $(\mathrm{TnBP})$ and Tris buffer solution for $24 \mathrm{~h}$ at room temperature according to previously established protocol [27]. This was followed by two $24 \mathrm{~h}$ rinses in deionized water and a $24 \mathrm{~h}$ rinse in $70 \%(\mathrm{v} / \mathrm{v})$ ethyl alcohol.

\subsubsection{Conjugation of Nanomaterials}

Nanoparticles were purchased from Ted Pella, Inc. (Redding, CA). Concentrations refer to concentration of nanoparticles used in crosslinking procedure relative to the initial concentration given by the supplier. $1 \mathrm{x}$ concentration refers to $7.0 \times 10^{11}$ for $20 \mathrm{~nm}$ AuNP and to $5.6 \times 10^{9}$ for $100 \mathrm{~nm}$ AuNP. $4 \mathrm{x}$ and $8 \mathrm{x}$ concentration are 4 and 8 times as concentrated as $1 x$ concentrations, respectively. Attachment of AuNP to tissue was conducted according to a previously established protocol [15]. AuNP were functionalized with $15 \mu \mathrm{M}$ 2-mercaptoethylamine (MEA) prior to conjugation. Tissue was incubated for $15 \mathrm{~min}$ in crosslinking solution containing 50:50 (v/v) solution of acetone and $1 \mathrm{x}$ phosphate buffered saline (PBS) ( $\mathrm{pH}=7.5)$ with $2 \mathrm{mM}$ 1-ethyl-3-[3-dimethylainopropyl] carbodiimide (EDC) first dissolved in $0.1 \mathrm{M} 2-(\mathrm{N}$-Morpholino) ethanesulfonic acid (MES) in $0.5 \mathrm{M}$ sodium chloride $(\mathrm{NaCl})(\mathrm{pH}=6.0)$ and $5 \mathrm{mM} N$-hydroxysuccinimide (NHS) first dissolved in dimethylformamide (DMF). Tissue was removed from crosslinking solution and specified concentration of AuNP was added to cover tissue ( $1 \mathrm{x}, 4 \mathrm{x}$, and $8 \mathrm{x}$ as described above). After $2 \mathrm{~h}$, tissue was rinsed twice in $1 \mathrm{x}$ PBS for $24 \mathrm{~h}$ each. The tissue group denoted as "crosslinked" received crosslinking treatment without the addition of the nanoparticle solution. The tissue group denoted as "decellularized" did not receive crosslinking treatment. Tissue groups are labeled according to their crosslinking treatment, AuNP size, and AuNP concentration. For example, tissue constructs conjugated with $20 \mathrm{~nm}$ AuNP at a $4 \mathrm{x}$ concentration are referred to as $4 \times 20 \mathrm{~nm}$ constructs.

\subsubsection{Tissue Homogenization}

Tissue sections in 1x PBS were placed in a Tissue Lyser II (Qiagen, Hilden, Germany) with stainless steel beads for $15 \mathrm{~min}$ at $30 \mathrm{~Hz}$ at room temperature. Tissue was further homogenized using a blade homogenizer on ice for another $15 \mathrm{~min}$. Homogenized tissue was stored in $1 \mathrm{x}$ PBS at $4^{\circ} \mathrm{C}$. When ready for analysis, tissue was centrifuged to sediment tissue at bottom of tube and supernatant was removed. Centrifugation and decanting were repeated and homogenized tissue was stirred.

\subsubsection{Sterilization}

Homogenized tissue was sterilized in sterilization solution containing $0.1 \%(\mathrm{v} / \mathrm{v})$ peracetic acid $(\mathrm{pH} 7)$ at room temperature. Sterilization solution was passed through a $0.22 \mu \mathrm{m}$ sterile filter unit before being added to homogenized tissue. Tissue was incubated with sterilization solution for $30 \mathrm{~min}$ with agitation (225 
rpm). Samples were centrifuged and the supernatant was removed to remove sterilization solution. To rinse, sterile PBS was added to the tissue, samples were centrifuged, and supernatant was removed. Rinsing was repeated 3 times.

\subsection{Electron Microscopy}

Samples were prepared for scanning electron microscopy (SEM) imaging by fixation in $0.1 \mathrm{M}$ sodium cacodylate buffer (2\% glutaraldehyde and $2 \%$ paraformaldehyde $(\mathrm{pH}=7.35)$ ). Samples were then dehydrated by microwaved graded ethyl alcohol rinses $(20 \%, 50 \%, 70 \%, 90 \%$, and $100 \%)$. Critical point drying in a Tousimis Auto-Samdri 815 automatic critical point dryer (Tousimis, Rockville, $\mathrm{MD}$ ) was performed, and samples were then placed on a carbon tape stub and sputter-coated with carbon using an Emitech K575X Peltier cooled sputter coater (Emitech, Houston, TX). An FEI Quanta 600FEG Environmental SEM (FEI Company, Hillsboro, OR) was used for imaging and energy-dispersive x-ray spectroscopy (EDS).

\subsection{Differential Scanning Calorimetry}

Differential Scanning Calorimetry (DSC) was performed using a Q2000 DSC (TA Instruments, New Castle, DE). Approximately 9 - $14 \mathrm{mg}$ of homogenized tissue sample was sealed with $2 \mu \mathrm{L}$ of deionized water in aluminum pans with a hermetic lid. Samples were run in triplicate $(\mathrm{n}=3)$ from $-5^{\circ} \mathrm{C}$ to $120^{\circ} \mathrm{C}$ at a rate of $3^{\circ} \mathrm{C}$ per minute modulation every 80 seconds $\pm 0.64^{\circ} \mathrm{C}$. Universal Analysis software integration tool was used to determine the onset denaturation temperature and denaturation temperature from the non-reversing heat flow signal.

\subsection{Extrusion Force Testing}

Each construct group was loaded into a syringe connected to a 20-gauge cannula. The syringes were secured into an Instron 584 Universal Testing Machine (Instron, Norwood, MA) in compressive mode. Force was measured over a constant rate of displacement. The syringes were run for $30 \mathrm{~mm}$ at a rate of 0.167 $\mathrm{mm} / \mathrm{sec}$ with force measurements taken every $0.1 \mathrm{sec}$. Maximum extrusion force was taken from all compressive force data points over the $30 \mathrm{~mm}$ extension.

\subsection{Cell Culture}

L-929 murine fibroblast cells were purchased from ATCC (Manassas, VA) and cultured at $37^{\circ} \mathrm{C}$ and $5 \% \mathrm{CO}_{2}$ in Eagle's Minimum Essential Medium (EMEM) supplemented with $10 \%(\mathrm{~V} / \mathrm{v})$ horse serum and $200 \mathrm{U} / \mathrm{mL}$ Penn Strep. Cells were subcultured and given fresh cell media as needed. All assays were conducted using L-929 murine fibroblast cells, and all assays were performed in a biological safety cabinet under sterile conditions.

\subsection{Cell Viability and Proliferation Assay}

A Quant-iT ${ }^{\mathrm{TM}} \mathrm{dsDNA}^{\oplus}$ Pico Green assay (Life Technologies, Grand Island, NY) was performed using the manufacturer's protocol to measure cell proliferation. 
Homogenized tissue was added to a 96-well plate and seeded with $0.75 \times 10^{4}$ cells/mL with four replicates for each sample type $(n=4)$. Cells were cultured for 3, 7, and 10 days with media changes every other day. Samples were removed from well plate, lyophilized, and digested with papain digestion buffer containing $125 \mu \mathrm{g} / \mathrm{mL}$ papain in PBE buffer containing sterile PBS with $5 \mathrm{mM}$ cysteine- $\mathrm{HCl}$ and $5 \mathrm{mM} \mathrm{Na}{ }_{2}$ EDTA. The resulting digest, $1 \mathrm{x}$ TE buffer in DNase-free water, and the Quant-iT ${ }^{\mathrm{TM}}$ PicoGreen dsDNA reagent (Invitrogen Corporation, Carlsbad, CA) were incubated away from light for $5 \mathrm{~min}$. A Synergy H-1 MultiMode microplate reader (Biotek Instruments, Inc., Winooski, VT) was used to measure fluorescence intensity at $520 \mathrm{~nm}$ emissions with $480 \mathrm{~nm}$ excitation. Double-stranded DNA (dsDNA) concentration was determined by interpolation from linear regression analysis using a five point lambda DNA standard.

\subsection{ROS Assay}

ROS activity was measured following the manufacturer's protocol for an OxiSelect $^{\mathrm{TM}}$ ROS Assay kit (Cell Biolabs, Inc., San Diego, CA). Fibroblasts were seeded onto a 96 -well plate at $3.7 \times 10^{4}$ cells/well in $200 \mu \mathrm{L}$ of supplemented EMEM with five replicates for each sample type $(n=5)$. Cells we allowed to become confluent overnight at $37^{\circ} \mathrm{C}$ and $5 \% \mathrm{CO}_{2}$. Each well was rinsed with DPBS and 1x 2',7'-Dichlorodihydrofluorescin diacetate (DCF-DA)/EMEM was added. The plate was incubated for $1 \mathrm{~h}$ at $37^{\circ} \mathrm{C}$ and $5 \% \mathrm{CO}_{2}$. The $1 \mathrm{x}$ DCF-DA/EMEM was removed and wells were rinsed twice with DPBS. Each well had $50 \mu \mathrm{L}$ of lyophilized homogenized tissue and $100 \mu \mathrm{L}$ of EMEM added before incubation at $37^{\circ} \mathrm{C}$ and $5 \% \mathrm{CO}_{2}$ for $12 \mathrm{~h}$. Cell lysis buffer was added to each well and incubated at room temperature for $5 \mathrm{~min}$. Solution was transferred to a new 96 -well plate and fluorescence intensity was read on a Synergy H-1 Multi-Mode microplate reader (Biotek Instruments, Inc., Winooski, VT) at $480 \mathrm{~nm}$ excitation and $530 \mathrm{~nm}$ emission. DCF concentration was determined by interpolation from linear regression analysis using an eight point DCF standard.

\subsection{Cell Migration Assay}

A CytoSelect ${ }^{\mathrm{TM}}$ Cell Migration assay (Cell BioLabs, San Diego, CA) was conducted according to the manufacturer's protocol. $50 \mu \mathrm{L}$ of homogenized tissue and $100 \mu \mathrm{L}$ serum-free media were added to each well of the lower chamber of a 96-well plate using a sterile 18-gauge cannula with eight replicated for each sample type $(n=8)$. Fibroblasts were suspended in serum-free media and $2.5 \times 10^{4}$ cells were added to the upper chamber of each well with $100 \mu \mathrm{L}$ of serum-free media. Cells were allowed to migrate across the membrane for $24 \mathrm{~h}$ at $37^{\circ} \mathrm{C}$ and $5 \% \mathrm{CO}_{2}$. Media was removed from the upper chamber and the upper chamber was removed from the bottom plate. The upper chamber was placed in the harvesting tray containing cell detachment solution and incubated for $30 \mathrm{~min}$ at $37^{\circ} \mathrm{C}$. Cells were dislodged by gently tilting tray. Lysis Buffer/CyQuant GR dye solution was added to each well containing cells and detachment solution and incubated for $20 \mathrm{~min}$ at room temperature. Solutions were transferred to a new 
96-well plate and read on a Synergy H-1 Multi-Mode microplate reader (Biotek Instruments, Inc., Winooski, VT) at $480 \mathrm{~nm}$ excitation and $520 \mathrm{~nm}$ emission. Cell migration is presented as the relative fluorescence intensity of a sample compared to wells with serum-free media only.

\subsection{Statistical Analysis}

Statistical analyses were conducted using SAS 9.4 software. A one-way analysis of variance (ANOVA) with a pair-wise Tukey test using the PROC GLM procedure was conducted to determine significant differences at a $\mathrm{p}<0.05$ significance level. Linear regression analysis with a standard curve was to interpolate fluorescence intensity values and was conducted using the PROC REG procedure. Values from DSC, cell proliferation assays, ROS assays, and cell migration assays are presented as mean values $+/-$ standard error of the mean calculated using Origin 9.1 software.

\section{Results}

\subsection{Electron Microscopy}

SEM and EDS analysis were conducted to confirm attachment of AuNP to homogenized tissue and to ensure that the treatment processes did not damage tissue. The open microstructure of constructs was maintained during crosslinking and homogenization as seen in Figure 1. Attachment of AuNP to tissue is confirmed in Figure 2. AuNP can be seen as small, bright circular features within fainter ECM. Features are confirmed to be AuNP by observing energy peaks at $2.1 \mathrm{keV}$ and at $9.7 \mathrm{keV}$ from EDS analysis (results not shown).

\subsection{Differential Scanning Calorimetry}

DSC values for onset denaturation temperature and denaturation temperature are given in Figure 3. For onset denaturation temperature, crosslinked, $1 \times 20$ $\mathrm{nm}, 1 \times 100 \mathrm{~nm}, 4 \times 100 \mathrm{~nm}$, and $8 \times 100 \mathrm{~nm}$ constructs have significantly higher mean temperatures $(n=3)$ than decellularized and $8 \times 20 \mathrm{~nm}$ constructs. Crosslinked constructs have a significantly higher mean temperature than de-

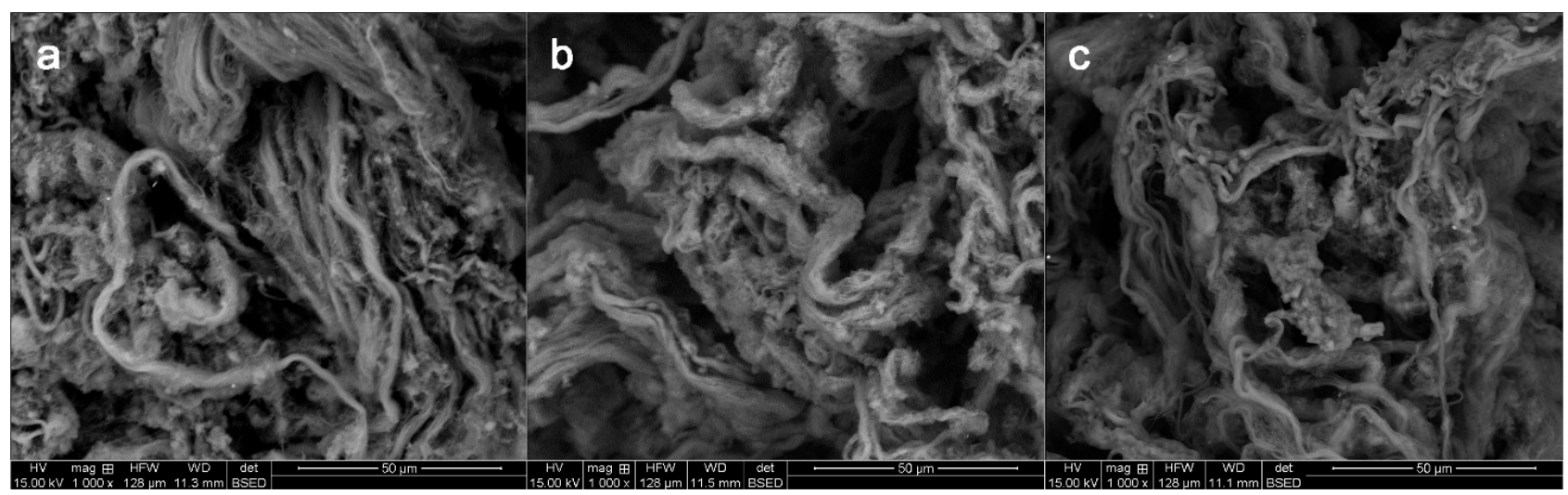

Figure 1. SEM images of constructs confirming similar microstructure between construct types. All constructs demonstrate an open microstructure. (a) Decellularized construct. (b) Crosslinked construct. (c) $4 \times 100 \mathrm{~nm}$ construct. 


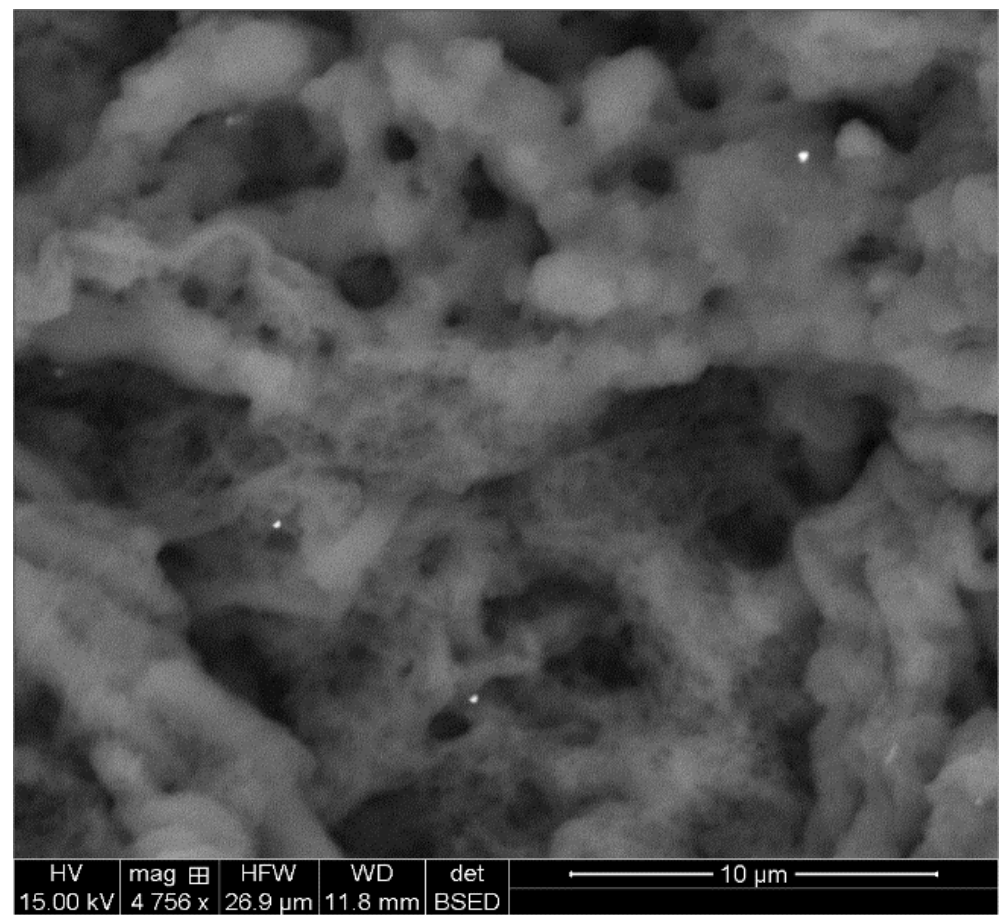

Figure 2. SEM image of $1 \times 100 \mathrm{~nm}$ construct confirming presence of AuNP by the presence of small, bright spheres within fainter ECM.

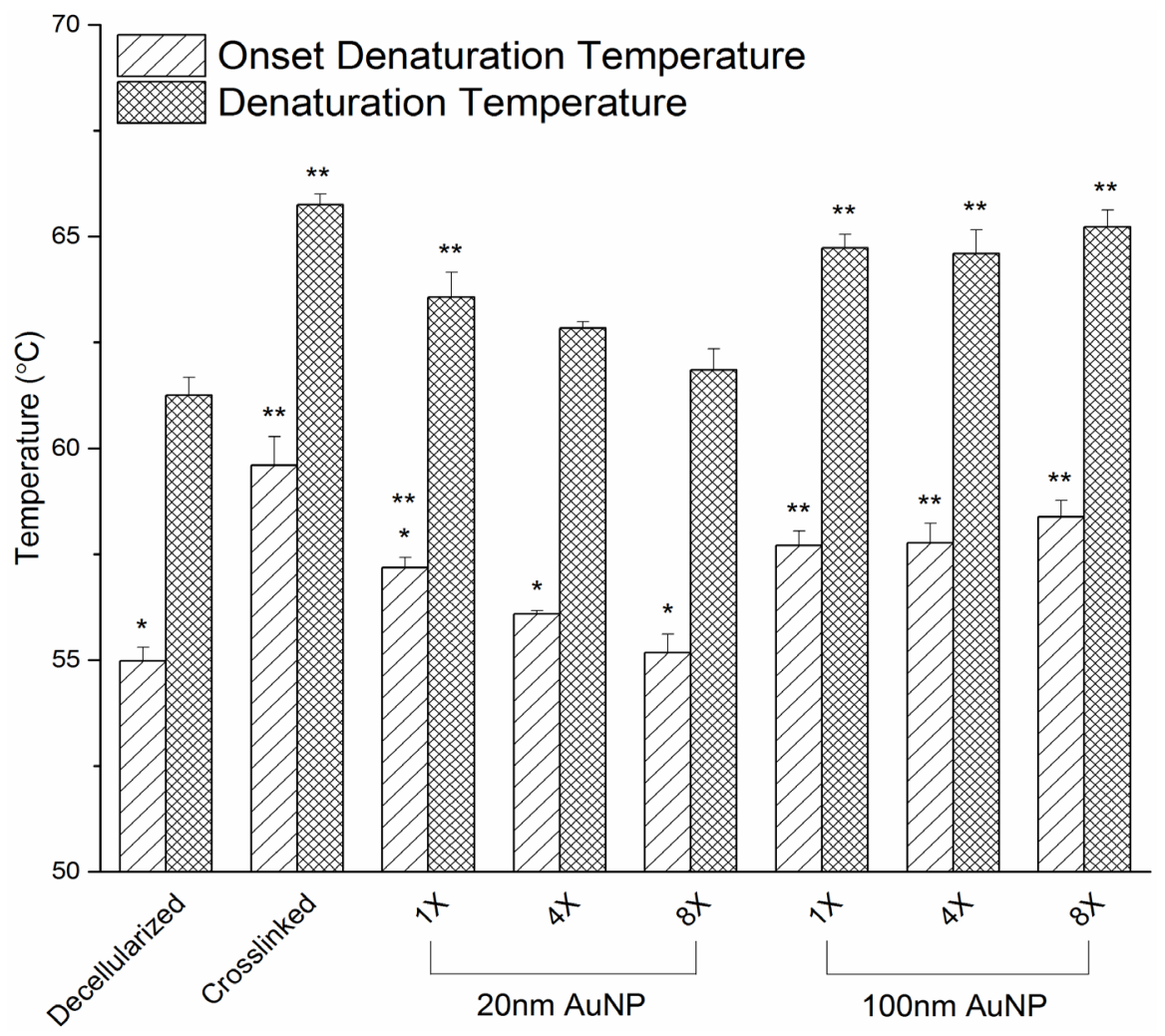

Figure 3. DSC results showing onset denaturation temperature and denaturation temperature. ${ }^{\star}$ Indicates constructs with significantly lower mean temperatures compared to crosslinked constructs. ${ }^{* \star}$ Indicates constructs with significantly higher mean temperatures than decellularized and $8 \times 20 \mathrm{~nm}$ constructs. $\mathrm{n}=3$. Error bars are given as standard error of the mean. $\mathrm{p}<0.05$. 
cellularized, $1 \times 20 \mathrm{~nm}, 4 \times 20 \mathrm{~nm}$, and $8 \times 20 \mathrm{~nm}$ constructs. In addition, $8 \times$ $100 \mathrm{~nm}$ constructs have a higher mean temperature than the $4 \times 20 \mathrm{~nm}$ constructs. For denaturation temperature, crosslinked, $1 \times 20 \mathrm{~nm}, 1 \times 100 \mathrm{~nm}, 4 \times$ $100 \mathrm{~nm}$, and $8 \times 100 \mathrm{~nm}$ constructs have significantly higher mean denaturation temperatures than decellularized constructs. Crosslinked, $1 \times 100 \mathrm{~nm}, 4 \times 100$ $\mathrm{nm}$, and $8 \times 100 \mathrm{~nm}$ constructs have significantly higher mean denaturation temperatures than $8 \times 20 \mathrm{~nm}$ constructs. Crosslinked constructs have a significantly higher mean denaturation temperature than decellularized, $1 \times 20 \mathrm{~nm}, 4$ $\times 20 \mathrm{~nm}$, and $8 \times 20 \mathrm{~nm}$ constructs. In addition, $8 \times 100 \mathrm{~nm}$ constructs have a higher mean denaturation temperature than $4 \times 20 \mathrm{~nm}$ constructs.

\subsection{Extrusion Force Testing}

Extrusion force measurements of syringes filled with constructs were measured every $0.1 \mathrm{sec}$ at a constant rate of displacement over $30 \mathrm{~mm}$. Maximum extrusion forces were taken from all compressive force data points over the $30 \mathrm{~mm}$ extension and are presented in Table 1 . The lowest maximum compressive force value is $1.72 \mathrm{~N}$ and the highest is $3.82 \mathrm{~N}$.

\subsection{Cell Viability and Proliferation Assay}

Results of the 3, 7, and 10 day cell viability and proliferation assay are given in Figure 4. A PicoGreen dsDNA assay was used to determine dsDNA content of tissue constructs. The only significant difference within a single group between different days is that $1 \times 20 \mathrm{~nm}$ constructs have a significantly higher mean dsDNA content $(\mathrm{n}=4)$ at 10 days compared to $1 \times 20 \mathrm{~nm}$ constructs at both 3 and 7 days. At 3 days, crosslinked, $4 \times 20 \mathrm{~nm}, 8 \times 20 \mathrm{~nm}, 4 \times 100 \mathrm{~nm}$, and $8 \times$ $100 \mathrm{~nm}$ constructs have significantly higher mean dsDNA contents than decellularized constructs. Crosslinked, $1 \times 20 \mathrm{~nm}, 4 \times 20 \mathrm{~nm}, 8 \times 20 \mathrm{~nm}, 4 \times 100 \mathrm{~nm}$, and $8 \times 100 \mathrm{~nm}$ constructs have a significantly higher mean dsDNA content than $1 \times 100 \mathrm{~nm}$ constructs at 3 days. At 7 days, $1 \times 20 \mathrm{~nm}$ constructs have a significantly higher mean dsDNA content than decellularized, crosslinked, $4 \times$ $20 \mathrm{~nm}, 8 \times 20 \mathrm{~nm}$, and $1 \times 100 \mathrm{~nm}$ constructs. $8 \times 100 \mathrm{~nm}$ constructs have a significantly higher mean dsDNA content than decellularized constructs at 7 days.

Table 1. Extrusion force of homogenized tissue constructs through a 20 gauge cannula.

\begin{tabular}{cc}
\hline Construct type & Maximum extrusion force $(\mathrm{N})$ \\
\hline Decellularized & 1.72 \\
Crosslinked & 2.05 \\
$1 \mathrm{X}-20 \mathrm{~nm}$ & 3.82 \\
$4 \mathrm{X}-20 \mathrm{~nm}$ & 3.46 \\
$8 \mathrm{X}-20 \mathrm{~nm}$ & 1.81 \\
$1 \mathrm{X}-100 \mathrm{~nm}$ & 2.19 \\
$4 \mathrm{X}-100 \mathrm{~nm}$ & 3.15 \\
$8 \mathrm{X}-100 \mathrm{~nm}$ & 2.75
\end{tabular}




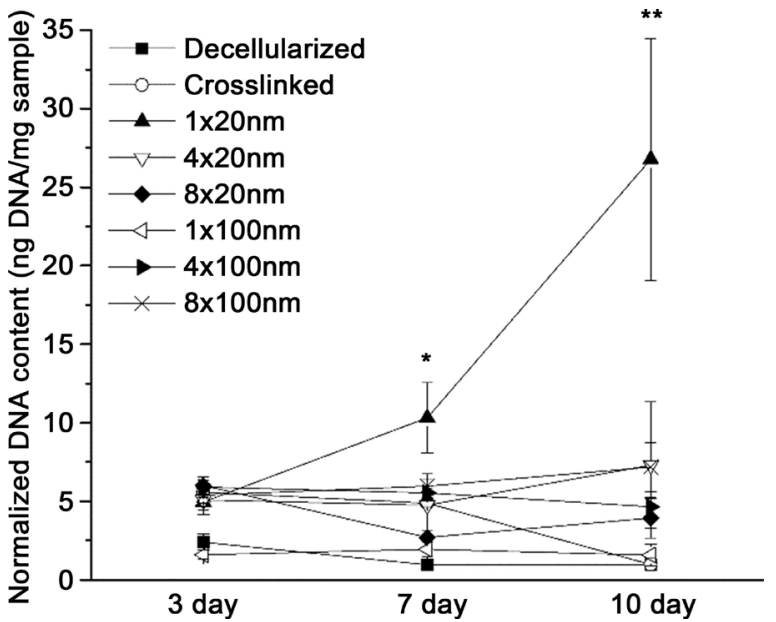

Figure 4. PicoGreen assay results of constructs at 3, 7 and 10 day time points. ${ }^{\star}$ Indicates significantly higher DNA content compared to decellularized, crosslinked, $4 \times 20 \mathrm{~nm}, 8 \times$ $20 \mathrm{~nm}$, and $1 \times 100 \mathrm{~nm}$ constructs. ${ }^{*}$ Indicates significantly higher DNA content than decellularized, crosslinked, $4 \times 20 \mathrm{~nm}, 8 \times 20 \mathrm{~nm}, 1 \times 100 \mathrm{~nm}, 4 \times 100 \mathrm{~nm}$, and $8 \times 100$ $\mathrm{nm}$ constructs. $\mathrm{n}=4$. Error bars are given as standard error of the mean. $\mathrm{p}<0.05$.

At 10 days, $1 \times 20 \mathrm{~nm}$ constructs have a significantly higher dsDNA content than decellularized, crosslinked, $4 \times 20 \mathrm{~nm}, 8 \times 20 \mathrm{~nm}, 1 \times 100 \mathrm{~nm}, 4 \times 100 \mathrm{~nm}$, and $8 \times 100 \mathrm{~nm}$ constructs.

\subsection{ROS Assay}

ROS assay results are given in Figure 5. An OxiSelect ${ }^{\mathrm{Tm}}$ ROS Assay kit was used calculate the relative DCF concentration of cells cultured with tissue constructs that directly correlates to ROS concentration. $1 \times 20 \mathrm{~nm}, 4 \times 20 \mathrm{~nm}, 8 \times 20 \mathrm{~nm}$, and $8 \times 100 \mathrm{~nm}$ constructs have significantly lower mean DCF concentrations than decellularized constructs $(\mathrm{n}=5)$. Additionally, $4 \times 20 \mathrm{~nm}$ constructs have a significantly lower mean DCF concentration compared to $1 \times 100 \mathrm{~nm}$ constructs.

\subsection{Cell Migration Assay}

Migration assay results are given in Figure 6. A Cyto Select ${ }^{\mathrm{TM}}$ Cell Migration assay was conducted using homogenized tissue constructs as a chemoattractant and the relative amount of migrated cells was measured by fluorescence intensity. There is a significantly higher mean fluorescence intensity on $4 \times 20 \mathrm{~nm}$ constructs compared to crosslinked, $1 \times 100 \mathrm{~nm}, 4 \times 100 \mathrm{~nm}$, and $8 \times 100 \mathrm{~nm}$ constructs $(n=8)$.

\section{Discussion}

Injectable tissue constructs fabricated from ECM and AuNP are developed for potential musculoskeletal tissue engineering applications. Amine-functionalized AuNP of $20 \mathrm{~nm}$ or $100 \mathrm{~nm}$ were conjugated to decellularized porcine diaphragm tendon and homogenized into an injectable form. Tissue constructs were analyzed by SEM/EDS, DSC, extrusion force testing, cell viability and proliferation assays, ROS assays, and cell migration assays. 


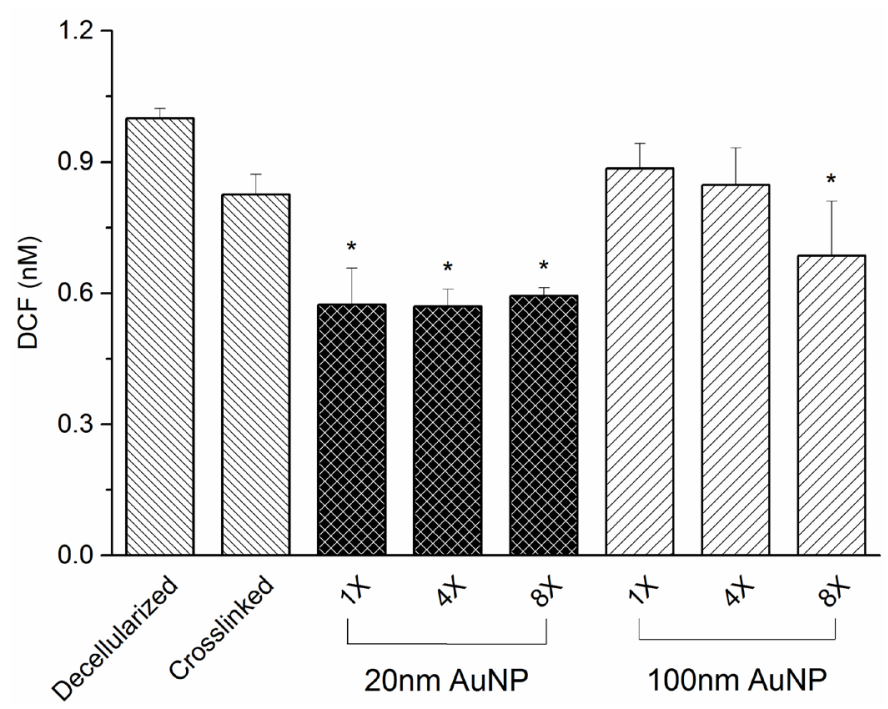

Figure 5. Intracellular ROS assay results for constructs. DCF concentration directly corresponds to intracellular ROS levels. ${ }^{\star}$ Indicates significantly lower DCF concentration compared to decellularized constructs. $n=5$. Error bars are given as standard error of the mean. $\mathrm{p}<0.05$.

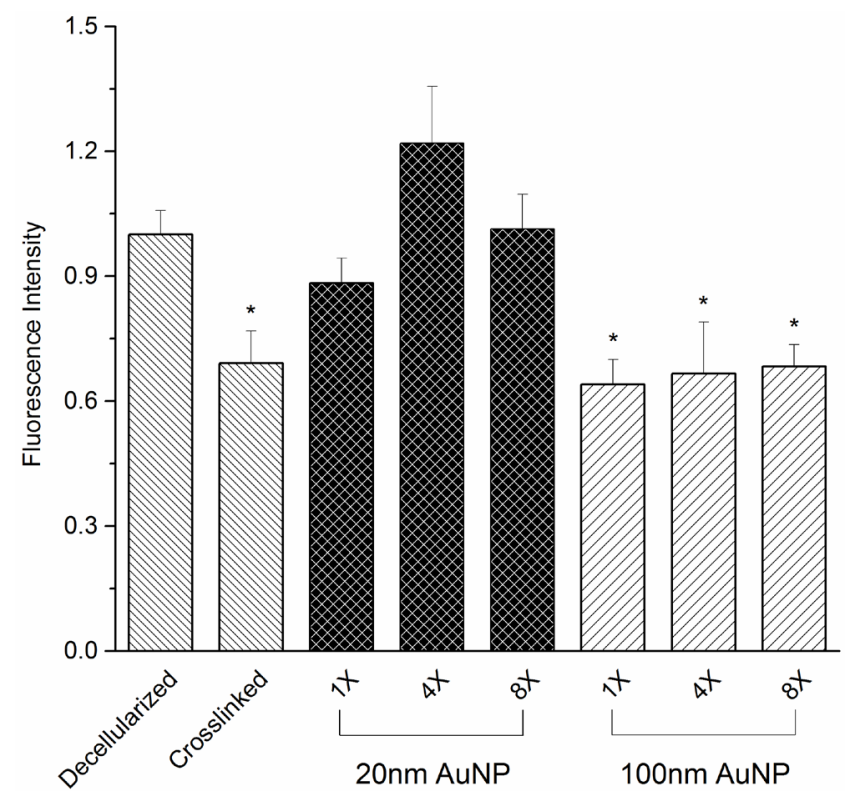

Figure 6. Migration assay results for constructs. Fluorescence intensity directly corresponds to migrated cell concentration. ${ }^{\star}$ Indicates constructs with significantly lower fluorescence intensity compared to $4 \times 20 \mathrm{~nm}$. $\mathrm{n}=8$. Error bars are given as standard error of the mean. $\mathrm{p}<0.05$.

SEM images and EDS analysis confirms an open microstructure of the constructs and attachment of AuNP to homogenized tissue (Figure 1 \& Figure 2). There are several advantages to attaching the AuNP to the tissue as opposed to incorporation by physical adsorption. Attachment prevents the AuNP from cellular uptake and from migration to other parts of the body. In addition, attachment prevents an immediate release of the AuNP allowing the construct to continually deliver the anti-inflammatory benefits of AuNP beyond initial implanta- 
tion. SEM images demonstrate an open microstructure of the constructs that is important for cellular infiltration. Excessive crosslinking may limit the porosity of the constructs, reducing the ability for cells to infiltrate and remodel the tissue potentially leading to poor in vivo performance [28]. It is also important to ensure that the processes of decellularization, crosslinking, homogenization, and sterilization do not damage the construct. SEM images reveal that the integrity of the ECM is retained through these processes.

DSC testing was performed to analyze the thermal stability and degree of crosslinking of the constructs (Figure 3 ). Notable significant differences include crosslinked, $1 \times 20 \mathrm{~nm}, 1 \times 100 \mathrm{~nm}, 4 \times 100 \mathrm{~nm}$, and $8 \times 100 \mathrm{~nm}$ constructs having significantly higher mean denaturation and onset denaturation temperatures compared to decellularized constructs. This difference confirms successful crosslinking since higher denaturation temperatures indicate a higher degree of crosslinking. Crosslinking may improve construct stability since low degrees of crosslinking are associated with more rapid in vivo degradation [28] [29]. On the other hand, excessive crosslinking can impede cell migration and cellular infiltration [28] [30]. It is important that the degree of crosslinking is sufficient enough to prevent quick degradation while still allowing cellular infiltration. Together, SEM images combined with denaturation temperatures confirm successful crosslinking while maintaining an open microstructure.

Crosslinked constructs have significantly higher mean denaturation and onset denaturation temperatures than $1 \times 20 \mathrm{~nm}, 4 \times 20 \mathrm{~nm}$, and $8 \times 20 \mathrm{~nm}$ constructs. This indicates that the addition of nanoparticles may ameliorate the potential excessive crosslinking that may occur during the crosslinking procedure. In addition, $8 \times 20 \mathrm{~nm}$ constructs have significantly lower denaturation and onset denaturation temperatures than many of the other groups and were not statistically different than the decellularized group. This suggests that the larger $8 \mathrm{x}$ concentration of $20 \mathrm{~nm}$ AuNP further reduces crosslinking in the construct. This may be due to additional conjugation of $20 \mathrm{~nm}$ AuNP compared with 100 nm AuNP due to size differences between the AuNP.

Extrusion force testing was performed to evaluate the ease of injection of the construct under forces and cannula gauges typically used for steroid injections into the knee (Table 1). A 20-gauge cannula was used to measure the extrusion force of all constructs. A gauge of 18 - 23 is commonly used for intra-articular injections of steroids into the knee [31] [32]. It is important to have a cannula that is large enough for the material to pass through while small enough for the physician to have control. In addition, the force required to eject the material should be minimal. If the size of the cannula is too small for the material to expel easily, it will require high forces to expel which may be dangerous to patients and physicians. Studies have shown that increasing the cannula size and the required force for injection has a negative effect on the physician's ability to control the syringe [33] [34]. A study was conducted on the extrusion forces of syringes expelled by rheumatoid arthritis patients with hand impairment [35]. The average maximum force patients were able to apply during the injection was 
33.21 $\mathrm{N}$ and $45.34 \mathrm{~N}$ for two different syringe types. The values found in our study of $\sim 1 \mathrm{~N}$ to $4 \mathrm{~N}$ are much less than those found in the cited study. In addition, the mean extrusion forces of porcine-collagen dermal fillers were measured to evaluate injectability [33]. The study found that the lowest collagen dermal filler had a mean extrusion force of $7.7 \pm 0.5$. This extrusion force was at an acceptable level to decrease clinician hand fatigue and to improve clinician hand control. All extrusion forces in this study were found to be less than the acceptable mean extrusion force found in the cited study. It is concluded that homogenized construct could be safely delivered using a 20-gauge cannula.

A cell viability and proliferation assay was performed to test the ability of fibroblasts to proliferate on the tissue constructs (Figure 4). Cell proliferation is seen as viability increases from progressive time points. The fact that only $1 \times 20$ $\mathrm{nm}$ constructs showed a significant increase in cell viability from 3 to 7 and 3 to 10 days demonstrates that less cell proliferation occurred on other groups compared to the $1 \times 20 \mathrm{~nm}$ constructs (Figure 4). Cell viability can be interpreted from the PicoGreen dsDNA assay by comparing the dsDNA content of construct groups at individual time points. At 3 days, crosslinked constructs and $4 \mathrm{x}$ and $8 \mathrm{x}$ concentrations of both $20 \mathrm{~nm}$ and $100 \mathrm{~nm}$ AuNP constructs have a higher cell viability than decellularized constructs. This indicates a potential benefit of crosslinking the tissue and well as using higher concentrations of both $20 \mathrm{~nm}$ and $100 \mathrm{~nm}$ AuNP. In addition, at 3 days, $4 \times 100 \mathrm{~nm}$ and $8 \times 100 \mathrm{~nm}$ constructs have a significantly higher cell viability than $1 \times 100 \mathrm{~nm}$ constructs. This result also suggests a possible cell viability benefit of using higher concentrations of $100 \mathrm{~nm}$ AuNP. At 7 days, $1 \times 20 \mathrm{~nm}$ had a significantly higher cell viability than decellularized, crosslinked, $4 \times 20 \mathrm{~nm}, 8 \times 20 \mathrm{~nm}$, and $1 \times 100 \mathrm{~nm}$ constructs leading to several conclusions. First, at 7 days the $1 \times 20 \mathrm{~nm}$ constructs maintained the higher cell viability compared with decellularized and crosslinked constructs present at 3 days. Second, at the same concentration, $1 \times 20 \mathrm{~nm}$ constructs have a higher cell viability than $1 \times 100 \mathrm{~nm}$ constructs demonstrating superior performance of $20 \mathrm{~nm}$ AuNP constructs compared to $100 \mathrm{~nm}$ AuNP constructs at a $1 \mathrm{X}$ concentration. The benefit of $20 \mathrm{~nm}$ AuNP may occur at a lower concentration than for $100 \mathrm{~nm}$ AuNP. In addition, the use of higher concentrations of $20 \mathrm{~nm}$ AuNP on constructs does not increase cell viability. Lastly, $8 \times$ $100 \mathrm{~nm}$ constructs had a significantly higher cell viability than crosslinked constructs at 7 days. This indicates that it may take higher concentrations of $100 \mathrm{~nm}$ AuNP to see an improvement in cell viability. At 10 days, $1 \times 20 \mathrm{~nm}$ constructs had a significantly higher cell viability compared to decellularized, crosslinked, 4 $\times 20 \mathrm{~nm}, 8 \times 20 \mathrm{~nm}, 1 \times 100 \mathrm{~nm}, 4 \times 100 \mathrm{~nm}$, and $8 \times 100 \mathrm{~nm}$ constructs. The 10 day time point builds on the 7 day time point that $1 \times 20 \mathrm{~nm}$ constructs show an increase over all other tissue constructs and there may be an advantage to using this $1 \times 20 \mathrm{~nm}$ constructs to increase cell viability.

There are several reasons why the $1 \times 20 \mathrm{~nm}$ constructs showed superior cell viability and were the only constructs to demonstrate cell proliferation. Cell adhesion is necessary for fibroblast proliferation. The topography of a surface will 
affect the degree of adhesion of the cells to a surface. It has been shown that AuNP of particular sizes affect cell adhesion by creating a topography favoring cellular adhesion [36]. The $1 \times 20 \mathrm{~nm}$ constructs in this study may have provided a more favorable surface for cellular adhesion compared to other constructs. In a recent study by Zhu et al., mouse fibroblasts favored adhesion on surfaces containing $35 \mathrm{~nm}$ AuNP [37]. Both the size and concentration of AuNP will affect the surface that the cell interacts with which ultimately affects cell adhesion.

Oxidative stress has the potential to induce cell and tissue damage by activating cellular pathways leading to inflammation, apoptosis, and negative effects on remodeling and cell proliferation [38]. The reduction of damaging ROS is important for the promotion of remodeling. AuNP have been used as an anti-inflammatory agent due to AuNP's ability to act as free radical scavengers [17] [18] [19] [21]. Reduction in cellular ROS due to AuNP has been shown to be concentration dependent [22]. Similar to the effects of proliferation and migration, the concentration and size of the nanoparticle affects how the cells interact with the particles [39]. Previous studies of cellular ROS concentrations on collagen-100 nm AuNP constructs have shown a concentration dependent decrease in ROS production [16]. Too high of a concentration of nanoparticles may induce toxicity or disruptive effects to cellular events. Too low of a concentration of nanoparticles may not be sufficient for cells to recognize or to have a beneficial effect. This study showed a reduction in ROS levels for constructs at all concentrations of $20 \mathrm{~nm}$ AuNP and for $1 \times 100 \mathrm{~nm}$ constructs compared to decellularized constructs (Figure 5). It is possible that using a 1x concentration of 100 $\mathrm{nm}$ AuNP is the upper concentration limit for free radical scavenging ability of $100 \mathrm{~nm}$ AuNP constructs. $20 \mathrm{~nm}$ AuNP showed decreased ROS at all concentrations suggesting that even at higher concentrations, $20 \mathrm{~nm}$ AuNP can still provide anti-oxidative effects. More studies need to be conducted to investigate the exact mechanism of the reduction of ROS by AuNP to more effectively tune the size and concentration of AuNP to be used for anti-inflammatory agents.

Cell migration is influenced by a variety of factors including cell type and nanoparticle characteristics. ECM has been shown to be a chemoattractant for cells as part of a constructive remodeling process [3] [40]. To further enhance the cell migration potential of the construct, AuNP were conjugated to the ECM prior to homogenization. It is known that the migration of cells to nanoparticles depends on the nanoparticle size as well as cell type [41] [42]. A recent study by Hung et al. demonstrated that nanocomposites of collagen and $5 \mathrm{~nm}$ AuNP promoted enhanced migration of MSC's although it is not well known how AuNP modulate the effect [43]. In a study by Yang et al., migration of human dermal fibroblasts in the presence of $90 \mathrm{~nm}$ AuNP was increased compared to cells without [41]. Fibroblast cells have complex cytoskeletal networks that use lamellipodia to adhere to surfaces and regulate cell migration. These types of cells are more susceptible to differences in AuNP charge, size and shape due to the microtubule networks. Cell migration assay results demonstrated a higher indica- 
tion of migrated cells towards $4 \times 20 \mathrm{~nm}$ constructs compared to crosslinked and all concentrations of $100 \mathrm{~nm}$ AuNP constructs (Figure 6). It may be possible that the $4 \times 20 \mathrm{~nm}$ constructs promote a more favorable point of contact for cells compared with the $100 \mathrm{~nm}$ AuNP, increasing attachment to facilitate migration [41].

In summary, results support that constructs conjugated with AuNP demonstrate superior in vitro performance over constructs without nanoparticles. Further, $20 \mathrm{~nm}$ AuNP appear to have enhanced cell viability, cell proliferation, ROS reduction and cell migration induction over $100 \mathrm{~nm}$ AuNP at varying concentrations. Future studies involve further optimization of nanoparticle concentration and evaluation of in vivo performance.

\section{Conclusion}

Constructs proposed for intra-articular injection for musculoskeletal tissue engineering applications were fabricated from ECM and $100 \mathrm{~nm}$ or $20 \mathrm{~nm}$ AuNP. Results confirm the successful AuNP attachment, thermal stability, and injectability of the constructs. Fibroblast cell assays demonstrate enhanced cell viability and proliferation on $1 \times 20 \mathrm{~nm}$ constructs. ROS assays indicate a reduction in ROS on constructs with all concentrations of $20 \mathrm{~nm}$ AuNP and on constructs with the highest concentration of $100 \mathrm{~nm}$ AuNP. Migration assays indicate enhanced fibroblast migration towards $4 \times 20 \mathrm{~nm}$ constructs. These results supported the hypothesis and demonstrated possible benefits to utilize AuNP and particularly $20 \mathrm{~nm}$ AuNP, in an ECM construct for the use as an injectable tissue construct for musculoskeletal tissue engineering applications.

\section{Acknowledgements}

The authors would like to thank Allison Ostdiek for contributing to this work. This material is based upon work supported by the National Science Foundation under Grant No. 0943941.

\section{References}

[1] Brown, B.N. and Badylak, S.F. (2014) Extracellular Matrix as an Inductive Scaffold for Functional Tissue Reconstruction. Translational Research, 163, 268-285.

[2] Badylak, S.F., Freytes, D.O. and Gilbert, T.W. (2009) Extracellular Matrix as a Biological Scaffold Material: Structure and Function. Acta Biomaterialia, 5, 1-13.

[3] Beattie, A.J., Gilbert, T.W., Guyot, J.P., Yates, A.J. and Badylak, S.F. (2009) Chemoattraction of Progenitor Cells by Remodeling Extracellular Matrix Scaffolds. Tissue Engineering Part A, 15, 1119-1125. https://doi.org/10.1089/ten.tea.2008.0162

[4] Adair-Kirk, T.L. and Senior, R.M. (2008) Fragments of Extracellular Matrix as Mediators of Inflammation. The International Journal of Biochemistry \& Cell Biology, 40, 1101-1110.

[5] O’Reilly, P.J., Gaggar, A. and Blalock, J.E. (2008) Interfering with Extracellular Matrix Degradation to Blunt Inflammation. Current Opinion in Pharmacology, 8, 242 248.

[6] Seif-Naraghi, S.B., Singelyn, J.M., Salvatore, M.A., Osborn, K.G., Wang, J.J., Sampat, 
U., Kwan, O.L., Strachan, G.M., Wong, J., Schup-Magoffin, P.J., Braden, R.L., Bartels, K., DeQuach, J.A., Preul, M., Kinsey, A.M., DeMaria, A.N., Dib, N. and Christman, K.L. (2013) Safety and Efficacy of an Injectable Extracellular Matrix Hydrogel for Treating Myocardial Infarction. Science Translational Medicine, 5, 173-125. https://doi.org/10.1126/scitranslmed.3005503

[7] Sicari, B.M., Dziki, J.L., Siu, B.F., Medberry, C.J., Dearth, C.L. and Badylak, S.F. (2014) The Promotion of a Constructive Macrophage Phenotype by Solubilized Extracellular Matrix. Biomaterials, 35, 8605-8612.

[8] Farnebo, S., Woon, C.Y., Schmitt, T., Joubert, L.M., Kim, M., Pham, H. and Chang, J. (2014) Design and Characterization of an Injectable Tendon Hydrogel: A Novel Scaffold for Guided Tissue Regeneration in the Musculoskeletal System. Tissue Engineering, Part A, 20, 1550-1561. https://doi.org/10.1089/ten.tea.2013.0207

[9] Freytes, D.O., Martin, J., Velanka, S.S., Lee, A.S. and Badylak, S.F. (2008) Preparation and Rheological Characterization of a Gel Form of the Porcine Urinary Bladder Matrix. Biomaterials, 29, 1630-1637.

[10] Choi, J.S., Yang, H.J., Kim, B.S., Kim, J.D., Kim, J.Y., Yoo, B., Park, K., Lee, H.Y. and Cho, Y.W. (2009) Human Extracellular Matrix (ECM) Powders for Injectable Cell Delivery and Adipose Tissue Engineering. Journal of Controlled Release: Official Journal of the Controlled Release Society, 139, 2-7.

[11] Wu, J., Ding, Q., Dutta, A., Wang, Y., Huang, Y.H., Weng, H., Tang, L. and Hong, Y. (2015) An Injectable Extracellular Matrix Derived Hydrogel for Meniscus Repair and Regeneration. Acta Biomaterialia, 16, 49-59.

[12] Lima, E., Guerra, R., Lara, V. and Guzman, A. (2013) Gold Nanoparticles as Efficient Antimicrobial Agents for Escherichia Coli and Salmonella Typhi. Chemistry Central Journal, 7, 11. https://doi.org/10.1186/1752-153X-7-11

[13] Cozad, M.J., Bachman, S.L. and Grant, S.A. (2011) Assessment of Decellularized Porcine Diaphragm Conjugated with Gold Nanomaterials as a Tissue Scaffold for Wound Healing. Journal of Biomedical Materials Research Part A, 99, 426-434. https://doi.org/10.1002/jbm.a.33182

[14] Grant, S.A., Deeken, C.R., Hamilton, S.R., Grant, D.A., Bachman, S.L. and Ramshaw, B.J. (2013) A Comparative Study of the Remodeling and Integration of a Novel AuNP-Tissue Scaffold and Commercial Tissue Scaffolds in a Porcine Model. Journal of Biomedical Materials Research Part A, 101, 2778-2787. https://doi.org/10.1002/jbm.a.34574

[15] Deeken, C.R., Esebua, M., Bachman, S.L., Ramshaw, B.J. and Grant, S.A. (2011) Assessment of the Biocompatibility of Two Novel, Bionanocomposite Scaffolds in a Rodent Model. Journal of Biomedical Materials Research Part B, 96, 351-359. https://doi.org/10.1002/jbm.b.31778

[16] Grant, S.A., Spradling, C.S., Grant, D.N., Fox, D.B., Jimenez, L., Grant, D.A. and Rone, R.J. (2014) Assessment of the Biocompatibility and Stability of a Gold Nanoparticle Collagen Bioscaffold. Journal of Biomedical Materials Research Part A, 102, 332-339. https://doi.org/10.1002/jbm.a.34698

[17] Jeon, K.I., Byun, M.S. and Jue, D.M. (2003) Gold Compound Auranofin Inhibits IkappaB Kinase (IKK) by Modifying Cys-179 of IKKbeta Subunit. Experimental \& Molecular Medicine, 35, 61-66. https://doi.org/10.1038/emm.2003.9

[18] Kim, N.H., Lee, M.Y., Park, S.J., Choi, J.S., Oh, M.K. and Kim, I.S. (2007) Auranofin Blocks Interleukin-6 Signalling by Inhibiting Phosphorylation of JAK1 and STAT3. Immunology, 122, 607-614. https://doi.org/10.1111/j.1365-2567.2007.02679.x

[19] Norton, S. (2008) A Brief History of Potable Gold. Molecular Interventions, 8, 120. https://doi.org/10.1124/mi.8.3.1 
[20] Lee, H., Lee, M.Y., Bhang, S.H., Kim, B.S., Kim, Y.S., Ju, J.H., Kim, K.S. and Hahn, S.K. (2014) Hyaluronate-Gold Nanoparticle/Tocilizumab Complex for the Treatment of Rheumatoid Arthritis. ACS Nano, 8, 4790-4798. https://doi.org/10.1021/nn500685h

[21] Chou, C.W., Hsu, S.H. and Wang, P.H. (2008) Biostability and Biocompatibility of Poly(ether)urethane Containing Gold or Silver Nanoparticles in a Porcine Model. Journal of Biomedical Materials Research Part A, 84, 785-794.

[22] Barathmanikanth, S., Kalishwaralal, K., Sriram, M., Pandian, S.R., Youn, H.S., Eom, S. and Gurunathan, S. (2010) Anti-Oxidant Effect of Gold Nanoparticles Restrains Hyperglycemic Conditions in Diabetic Mice. Journal of Nanobiotechnology, 8, 16. https://doi.org/10.1186/1477-3155-8-16

[23] Chen, J., Patil, S., Seal, S. and McGinnis, J.F. (2006) Rare Earth Nanoparticles Prevent Retinal Degeneration Induced by Intracellular Peroxides. Nature Nanotechnology, 1, 142-150. https://doi.org/10.1038/nnano.2006.91

[24] Yakimovich, N., Ezhevskii, A., Guseinov, D., Smirnova, L., Gracheva, T. and Klychkov, K. (2008) Antioxidant Properties of Gold Nanoparticles Studied by ESR Spectroscopy. Russian Chemical Bulletin, 57, 520-523. https://doi.org/10.1007/s11172-008-0080-1

[25] Mukherjee, P., Bhattacharya, R., Wang, P., Wang, L., Basu, S., Nagy, J.A., Atala, A., Mukhopadhyay, D. and Soker, S. (2005) Antiangiogenic Properties of Gold Nanoparticles. Clinical Cancer Research, 11, 3530-3534. https://doi.org/10.1158/1078-0432.CCR-04-2482

[26] Junn, E., Han, S.H., Im, J.Y., Yang, Y., Cho, E.W., Um, H.D., Kim, D.K., Lee, K.W., Han, P.L. and Rhee, S.G. (2000) Vitamin D3 Up-Regulated Protein 1 Mediates Oxidative Stress Via Suppressing the Thioredoxin Function. The Journal of Immunology, 164, 6287-6295. https://doi.org/10.4049/jimmunol.164.12.6287

[27] Deeken, C.R., White, A.K., Bachman, S.L., Ramshaw, B.J., Cleveland, D.S., Loy, T.S. and Grant, S.A. (2011) Method of Preparing a Decellularized Porcine Tendon Using Tributyl Phosphate. Journal of Biomedical Materials Research Part B, 96, 199-206. https://doi.org/10.1002/jbm.b.31753

[28] Burugapalli, K., Chan, J.C., Kelly, J.L. and Pandit, A.S. (2014) Efficacy of Crosslinking on Tailoring in Vivo Biodegradability of Fibro-Porous Decellularized Extracellular Matrix and Restoration of Native Tissue Structure: a Quantitative Study Using Stereology Methods. Macromolecular Bioscience, 14, 244-256. https://doi.org/10.1002/mabi.201300195

[29] Deeken, C.R., Bachman, S.L., Ramshaw, B.J. and Grant, S.A. (2012) Characterization of Bionanocomposite Scaffolds Comprised of Mercaptoethylamine-Functionalized Gold Nanoparticles Crosslinked to Acellular Porcine Tissue. Journal of Materials Science, Materials in Medicine, 23, 537-546.

https://doi.org/10.1007/s10856-011-4486-1

[30] Chang, Y., Tsai, C.C., Liang, H.C. and Sung, H.W. (2002) In Vivo Evaluation of Cellular and Acellular Bovine Pericardia Fixed with a Naturally Occurring Crosslinking Agent (Genipin). Biomaterials, 23, 2447-2457.

[31] Courtney, P. and Doherty, M. (2009) Joint Aspiration and Injection and Synovial Fluid Analysis. Best Practice \& Research Clinical Rheumatology, 23, 161-192.

[32] Monseau, A.J. and Nizran, P.S. (2013) Common Injections in Musculoskeletal Medicine. Primary Care, 40, 987-1000.

[33] Lorenc, Z.P., Nir, E. and Azachi, M. (2010) Characterization of Physical Properties and Histologic Evaluation of Injectable Dermicol-p35 Porcine-Collagen Dermal Filler. Plastic and Reconstructive Surgery, 125, 1805-1813. 
https://doi.org/10.1097/PRS.0b013e3181d0ac75

[34] Michael, A.A., Moorjani, G.R., Peisajovich, A., Park, K.S., Sibbitt, W.L. and Bankhurst, A.D. (2009) Syringe Size: Does It Matter in Physician-Performed Procedures? Journal of Clinical Rheumatology, 15, 56-60. https://doi.org/10.1097/RHU.0b013e31819c1fc4

[35] Sheikhzadeh, A., Yoon, J., Formosa, D., Domanska, B., Morgan, D. and Schiff, M. (2012) The Effect of a New Syringe Design on the Ability of Rheumatoid Arthritis Patients to Inject a Biological Medication. Applied Ergonomics, 43, 368-375.

[36] Cohen-Karni, T., Jeong, K.J., Tsui, J.H., Reznor, G., Mustata, M., Wanunu, M., Graham, A., Marks, C., Bell, D.C, Langer, R. and Kohane, D.S. (2012) Nanocomposite Gold-Silk Nanofibers. Nano Letters, 12, 5403-5406. https://doi.org/10.1021/nl302810c

[37] Zhu, M., Baffou, G., Meyerbröker, N. and Polleux, J. (2012) Micropatterning Thermoplasmonic Gold Nanoarrays to Manipulate Cell Adhesion. ACS Nano, 6, 72277233. https://doi.org/10.1021/nn302329c

[38] Marano, F., Hussain, S., Rodrigues-Lima, F., Baeza-Squiban, A. and Boland, S. (2011) Nanoparticles: Molecular Targets and Cell Signalling. Archives of Toxicology, 85, 733-741. https://doi.org/10.1007/s00204-010-0546-4

[39] Hung, H.S., Tang, C.M., Lin, C.H., Lin, S.Z., Chu, M.Y., Sun, W.S., Kao, W.C., Hsien-Hsu, H., Huang, C.Y. and Hsu, S.H. (2013) Biocompatibility and Favorable Response of Mesenchymal Stem Cells on Fibronectin-Gold Nanocomposites. PLoS $O N E, 8$, e65738. https://doi.org/10.1371/journal.pone.0065738

[40] Li, F., Li, W., Johnson, S.A., Ingram, D.A., Yoder, M.C. and Badylak, S.F. (2004) Low-Molecular-Weight Peptides Derived from Extracellular Matrix as Chemoattractants for Primary Endothelial Cells. Endothelium: Journal of Endothelial Cell Research, 11, 199-206. https://doi.org/10.1080/10623320490512390

[41] Yang, J.A., Phan, H.T., Vaidya, S. and Murphy, C.J. (2013) Nanovacuums: Nanoparticle Uptake and Differential Cellular Migration on a Carpet of Nanoparticles. Nano Letters, 13, 2295-2302. https://doi.org/10.1021/nl400972r

[42] Zhou, E.H., Watson, C., Pizzo, R., Cohen, J., Dang, Q., De Barros, P.M.F., Park, C.Y., Chen, C., Brain, J.D., Butler, J.P., Ruberti, J.W., Fredberg, J.J. and Demokritou, P. (2015) Assessing the Impact of Engineered Nanoparticles on Wound Healing Using a Novel in Vitro Bioassay. Nanomedicine, 9, 2803-2315. https://doi.org/10.2217/nnm.14.40

[43] Hung, H.S., Chang, C.H., Chang, C.J., Tang, C.M., Kao, W.C., Lin, S.Z., Hsieh, H.H., Chu, M.Y., Sun, W.S. and Hsu, S.H. (2014) In Vitro Study of a Novel Nanogold-Collagen Composite to Enhance the Mesenchymal Stem Cell Behavior for Vascular Regeneration. PLOS ONE, 9, 1-18.

https://doi.org/10.1371/journal.pone.0104019 


\section{List of Abbreviations}

$\begin{array}{ll}\text { AuNP } & \text { gold nanoparticles } \\ \text { DMF } & \text { dimethylformamide } \\ \text { DSC } & \text { Differential Scanning Calorimetry } \\ \text { dsDNA } & \text { Double-stranded DNA } \\ \text { ECM } & \text { extracellular matrix } \\ \text { EDC } & \text { 1-ethyl-3-[3-dimethylainopropyl] carbodiimide } \\ \text { EDS } & \text { energy-dispersive x-ray spectroscopy } \\ \text { EDTA } & \text { ethylenediaminetetraacedic acid } \\ \text { EMEM } & \text { Eagle's Minimum Essential Medium } \\ \text { MES } & \text { 2-(N-Morpholino) ethanesulfonic acid } \\ \text { NaCl } & \text { sodium chloride } \\ \text { NHS } & \text { N-hydroxysuccinimide } \\ \text { PBS } & \text { phosphate buffered saline } \\ \text { PMSF } & \text { phenylmethylsulfonyl } \\ \text { PTOA } & \text { post-traumatic osteoarthritis } \\ \text { ROS } & \text { reactive oxygen species } \\ \text { SEM } & \text { scanning electron microscopy } \\ \text { TnBP } & \text { tri(n-butyl) phosphate }\end{array}$

Submit or recommend next manuscript to SCIRP and we will provide best service for you:

Accepting pre-submission inquiries through Email, Facebook, LinkedIn, Twitter, etc. A wide selection of journals (inclusive of 9 subjects, more than 200 journals) Providing 24-hour high-quality service User-friendly online submission system Fair and swift peer-review system Efficient typesetting and proofreading procedure Display of the result of downloads and visits, as well as the number of cited articles Maximum dissemination of your research work

Submit your manuscript at: http://papersubmission.scirp.org/

Or contact jbnb@scirp.org 